\title{
Moisture Content and Absorption Levels of Carbon Dioxide in Binuang Bini (Octomeles sumatrana Miq) Trees For Climate Change Management
}

\author{
Jacob Kailola $^{1 *}$, Gun Mardiatmoko ${ }^{2}$, Radios Simanjuntak ${ }^{1}$, Agustinus Kastanya ${ }^{2}$ \\ ${ }^{1}$ Forestry Department, Faculty of Natural Sciences and Engineering Technology, Halmahera University, Jl. Wari Raya, Tobelo, \\ Indonesia 97762 \\ ${ }^{2}$ Postgraduate Program, Pattimura University, J1. Ir. M. Putuhena, Ambon, Indonesia 97233
}

Received October 19, 2020/Accepted August 1, 2021

\begin{abstract}
Binuang bini (Octomeles sumatrana Miq) is a fast-growing tree with numerous economic benefits, such as the provision of wood for carpentry purposes, building boards, water management, and absorption of carbon dioxide $\left(\mathrm{Co}_{2}\right)$. Therefore, this tree species has great potential and needs to be included in Reducing Emission from Deforestation and Forest Degradation (REDD)+'s mitigation program to tackle climate change. In its development, REDD + has made it possible to carry out carbon trading in the world. Therefore, countries capable of performing protective functions and carry out reforestation, afforestation, and restoration, have the opportunity to be involved in world carbon trading. This study aims to determine the moisture content and carbon absorption rate of Binuang bini trees as a first step to regulate the allometric equation using destructive and laboratory analysis. The results show that the water content in the roots, leaves, as well as the base, middle, and tip of the stem were: 73.69\%, 68.39\%, $65.59 \%, 61.22 \%$, and $66.26 \%$, respectively. Furthermore, the sample test results indicate a very close relationship between carbon concentration and absorbance in the O.sumatrana tree with a simple linear regression equation: $Y$ $=0.002 X+0.0593 R^{2}=0.9896$. Therefore, this regression equation can be used to calculate the carbon concentration sample for the O. sumatrana tree fraction. The carbon content in 3 tree samples with a breast height diameter of $9.24 \mathrm{~cm}, 10.08 \mathrm{~cm}$, and $11.68 \mathrm{~cm}$ was $2.585 \mathrm{~kg}, 2.913 \mathrm{~kg}$, and 4,654 kg. In addition, the carbon sequestration for each tree diameter per year is $1.581 \mathrm{~kg} \mathrm{year}^{-1}, 1.782 \mathrm{~kg} \mathrm{year}^{-1}$ and $2.847 \mathrm{~kg} \mathrm{year}^{-1}$, respectively.
\end{abstract}

Keywords: carbon sequestration, biomass, moisture content, REDD +, climate change

*Correspondence author, email:jacobkailola@yahoo.co.id

\section{Introduction}

A forest is a large land area dominated by a collection of trees, with different microclimate and vegetation characteristics from its outside of area. According to Duncanson et al. (2010) and Luo et al. (2019), forests are important for the ecosystem due to their production of wood, bamboo, rattan, palm, honey, medicines, essential oils, etc. Besides that, they also have indirect benefits, such as erosion prevention, aesthetic value or natural beauty to be used as a tourist attraction, absorption of carbon $\left(\mathrm{CO}_{2}\right)$ elements, and regulating water system $\left(\mathrm{H}_{2} \mathrm{O}\right)$ (Estornell et al., 2011; Frazer et al., 2011; Singh et al., 2015; García et al., 2018). Today, many forests in the world are damaged due to degradation and deforestation (Zhang et al., 2016). These damages lead to climate change, which is characterized by the emergence of global warming due to the effects of greenhouse gases such as carbon dioxide $\left(\mathrm{CO}_{2}\right)$, methane $\left(\mathrm{CH}_{4}\right)$, nitrous oxide $\left(\mathrm{N}_{2} \mathrm{O}\right)$, hydrofluorocarbons (HFCS), perfluorocarbons (PFCS), and sulfur hexafluoride $\left(\mathrm{SF}_{6}\right)$ in the atmosphere.

One of the efforts to control climate change is through mitigation and adaptation (Huy et al., 2016). Mitigation activities are inseparable from the Reducing Emission from Deforestation and Forest Degradation (REDD+) program. This program is based on respecting individuals, communities, projects, and countries that can reduce greenhouse gas (GHG) emissions produced from forests (Littlefield et al., 2017; Chang et al., 2019). Furthermore, it can reduce GHG emissions at a low cost and within a short period, while reducing poverty and enabling sustainable development. REDD+ is one of the most obvious, cheapest, fastest, and mutually beneficial ways to reduce GHG emissions. It is real because approximately a fifth of GHG emissions come from deforestation and forest degradation. In addition, REDD + is also cheap because most forest degradation is only marginally profitable, therefore, it becomes cheaper to reduce GHG emissions from forests than other mitigation instruments. It is fast because large reductions in GHG emissions can be achieved by carrying out policy reforms and other measures that are not dependent on technological innovation. Subsequently, it is mutually beneficial because it has the potential to generate large amounts of income and improve governance. Therefore, it can benefit the poors in developing countries and provide other environmental benefits besides climate (Nurtjahjawilasa et al., 2013).

Although REDD+ is conceptually and mutually beneficial to the economy, its implementation is quite complicated. The measurement, reporting, and verification (MRV) system is basic and there is a need of significant requirement for implementing the REDD+ program using 
the principle of incentive that is valued based on performance. This system is responsible for measuring, monitoring, and reporting the emission level of forests periodically in a valid, accurate, transparent, holistic, and open manner, thereby allowing for quantitative valuation of REDD+ performance (Indonesia REDD+ Task Force, 2012; Stas et al., 2017; Randrianasolo et al., 2019). Another important factor is the uncertainty in the implementation of REDD+, namely the presence of additionality and leakage, which has encouraged numerous studies on forest biomass (Mardiatmoko, 2018). These studies are intended to determine the extent to which various forest types contribute to carbon sequestration or the development of allometric equations for various tree types to ensure they are used to estimate the amount of biomass produced from these tree species.

Data and information on carbon stocks in forest biomass and their spatial changes are needed to develop strategies for reducing GHG emissions due to deforestation and forest degradation to increase carbon stocks. Therefore, a comprehensive, credible, and verifiable National Carbon Accounting System is needed. One of the first steps in developing this system is carrying out studies on the inventory of tree biomass and volume allometric models to obtain references to allometric models suitable for specific conditions in Indonesia. In connection with this, a monograph of various allometric models for estimating tree biomass in various forest ecosystem types has been prepared in Indonesia (Mardiatmoko et al., 2020). However, the biomass and volume allometries of the $O$. sumatrana tree were not available in the monograph (Krisnawati et al., 2012). Therefore, this study seeks to determine the absorption rate of $\mathrm{CO}_{2}$ and $\mathrm{H}_{2} \mathrm{O}$ as well as the density value of $O$. sumatrana trees. The results from this research are expected to complement existing data and information on carbon stocks in forest biomass for addressing climate change (Quegan et al., 2019).

The $O$. sumatrana is a tree species from the Datiscaceae family and grows on mineral soils with an altitude of 0-600 $\mathrm{m}$ above sea level. The tree has a maximum height of $45 \mathrm{~m}$ with a trunk diameter of $30 \mathrm{~cm}$ or more and a fiber length of $1.536 \mathrm{~m}$ (Suhartati et al., 2012). In Indonesia, it has several regional names such as binuang, benuwang, binuang male (Sumatera), benuang bini, benuang, bunuang bini (Kalimantan), winuang, wenuang, benua motutu (Sulawesi), palaka, senao, walada (Maluku), buwar, kijare, jare (Papua). According to Martawijaya et al. (2005), $O$. sumatrana trees are distributed in Aceh, West Sumatera, South Sumatera, Sulawesi, Maluku, North Maluku, and Papua. During the plywood industry development in Maluku and North Maluku from 19902000, O. sumatrana was exploited as a significant raw material source for ply mills in both regions. Furthermore, numerous studies have been conducted to determine the physical and mechanical properties of the tree and insect pests of binuang because these plants are fast-growing and possess various advantages for the timber industry and planted forest development. There are many aspects of $O$. sumatrana that have been studied as described above, however, due to the lack of biomass data, this tree species is an option in this study.

\section{Methods}

Research location A sampling of binuang bini ( $O$. sumatrana) for this research was conducted in Wari Ino Village, Tobelo District, Halmahera Regency, North Maluku Province. Physical properties, water content, and specific

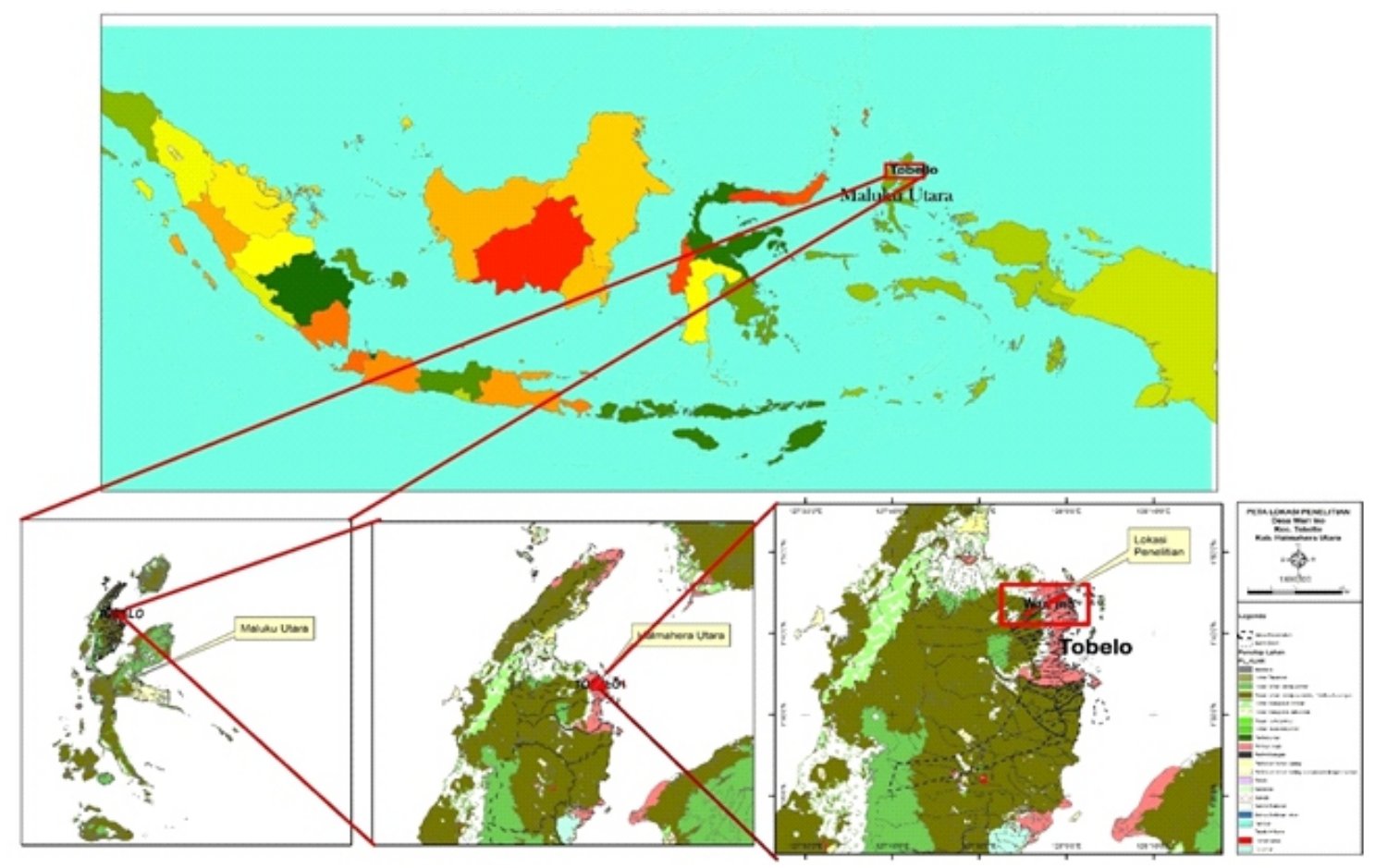

Figure 1 Map of the research location. 
gravity were analyzed at the Mathematics and Natural Science (MIPA) Laboratory of the University of Halmahera (UNIERA) Tobelo, while the carbon testing using the spectrophotometry method was analyzed at the MIPA Laboratory of the University of Pattimura (UNPATTI) Ambon. The research location is shown in Figure 1.

Data collection and analysis The early stages of field observation for sample determination of $O$. sumatrana were examined through laboratory analysis using three sample trees with a diameter at breast height (d.b.h) of $9.24 \mathrm{~cm}$, $10.08 \mathrm{~cm}$, and $11.68 \mathrm{~cm}$ and consecutive branch-free rods of $3 \mathrm{~m}, 3.5 \mathrm{~m}$, and $3.5 \mathrm{~m}$, respectively obtained from the City of Tobelo. Their moisture content and biomass were determined by taking the root components, stems, twigs, leaves as samples with American Standard Testing Material (ASTM D143, 1994; Kailola et al., 2019) and measuring the wet weight. Furthermore, it was inserted into the oven-dry kiln at a temperature of $100 \pm 3{ }^{\circ} \mathrm{C}$ until it was constant before obtaining the dry weight.

The formula for calculating biomass is shown in Equation [1] (Brown \& Iverson, 1992).

Total biomass (total weight $)=\mathrm{Wv}+\mathrm{Wb}+\mathrm{Wl}+\mathrm{Wt}$

Note: $\mathrm{Wv}=$ stem biomass with formula as shown in Equation [2], $\mathrm{Wb}=$ branch biomass with formula as shown in Equation [3], W1 = leaf biomass with formula as shown in Equation [4], $\mathrm{Wt}=$ root biomass with formula as shown in Equation [5].

Determination of carbon content with the spectrophotometer The carbon content is measured using the Walkley \& Black methods (Walkley \& Black, 1934) in the spectrophotometer with the stages of carbon analysis activities are as follows:

1. Moisture content measurements: This comprises weighing dry disc, placement of $1 \mathrm{~g}$ (BBSS) of plant organ sample powder into the disc, measuring the disc and wet weight of the powdered sample $(\mathrm{BC}+\mathrm{Bbss})$, importation of disc and plant organ powder $(\mathrm{BC}+\mathrm{Bbss})$ into the oven at temperatures of $103 \pm 2{ }^{\circ} \mathrm{C}$, and weighing and recording every decrease in weight until it is constant. It also consists of weighing and recording the disc and powder sample (BC + Bkss). Calculation of water weight was performed using the following formula as shown in Equation [6]

Table 1 Absorption rate of water content in binuang wood types

\begin{tabular}{lccc}
\hline \multicolumn{1}{c}{ Sample } & $\begin{array}{c}\text { Wet weight } \\
(\mathrm{g})\end{array}$ & $\begin{array}{c}\text { Dry weight } \\
\text { from oven }(\mathrm{g})\end{array}$ & $\begin{array}{c}\text { Moisture } \\
\text { content }(\%)\end{array}$ \\
\hline Root & 24.60 & 6.47 & 73.69 \\
Stem base & 28.05 & 9.65 & 65.59 \\
Stem middle & 15.86 & 6.15 & 61.22 \\
Stem tip & 18.31 & 6.18 & 66.26 \\
Leaf & 69.60 & 22.00 & 68.39 \\
\hline
\end{tabular}

$$
\mathrm{BA}(\mathrm{g})=(\mathrm{BC}+\mathrm{Bbss})-(\mathrm{BC}+\mathrm{Bkss})
$$

2. Analysis of carbon was conducted with a balance of airdried organ powder samples of $0.025 \mathrm{~g}$ (qualified 40 mesh) and weighed in a clean and dry watch glass. Powder samples were also placed in a $50 \mathrm{ml}$ volumetric flask, with an addition of $2.5 \mathrm{ml} \mathrm{K}_{2} \mathrm{Cr}_{2} \mathrm{O}_{7} 1 \mathrm{~N}$ using a pipette, and vigorously shaken. Consecutively, concentration $5 \mathrm{ml}$ of $\mathrm{H}_{2} \mathrm{SO}_{4}$, was added to the solution, which was whisked in a flat, rotated (extraction process), and cooled for 30 minutes. The obtained solution was added to $50 \mathrm{ml}$ of ion-free water to fit the size. The sample solution was left for 1 day after which a clear measurement of the absorption of the solution was carried out with a spectrophotometer at a wavelength of $561 \mathrm{~nm}$. Furthermore, comparisons were made with standard 0 and $250 \mathrm{ppm} \mathrm{C}$. For the standard containing $250 \mathrm{ppm} \mathrm{C}$, $2.5 \mathrm{ml}$ solution of $5,000 \mathrm{ppm} \mathrm{C}$ was added into the volumetric flask of $50 \mathrm{ml}$ using a pipette. In addition, 2.5 $\mathrm{ml}$ solution of $\mathrm{K}_{2} \mathrm{Cr}_{2} \mathrm{O}_{7}$ and $5 \mathrm{ml} \mathrm{H}_{2} \mathrm{SO}_{4}$ were used as the workmanship in the treatment of samples, with Blanko used as a standard at $0 \mathrm{ppm} \mathrm{C}$.

\section{Results and Discussion}

The tree of $O$. sumatrana absorption rate of $\mathrm{CO}_{2}$ and $\mathrm{H}_{2} \mathrm{O}$ Results based on the level of absorption of water (H2O), through the oven method and carbon dioxide $(\mathrm{CO} 2)$ by the spectrophotometric method shows that the roots' moisture content was higher than the base, middle, tip, and leaves (Table 1). Furthermore, Figure 2 shows the diagram of moisture content.

These results are in line with the research carried out by (Silooy, 1983; Kailola, 2006) who stated that the base has greater moisture content than the stem's middle and tip. This is due to cell wall formation occurring at the base, middle, and end of the stem. The cell walls at the base are thicker than the middle and ends, therefore, it has an impact on bound water, which occupies more of the cell walls. This is in line with the photosynthetic process that occurs in leaves, therefore, the water absorption rate at the end of the stem is higher than the middle.

The specific gravity of $O$. sumatrana using the klin over method on the roots was higher than the stem and branches (Table 2). According to Nuraeni et al. (2016) and Aprianis and Rahmayanri (2009), the O. sumatrana wood used as raw material for pulp has a specific gravity of 0.160 .48 , a

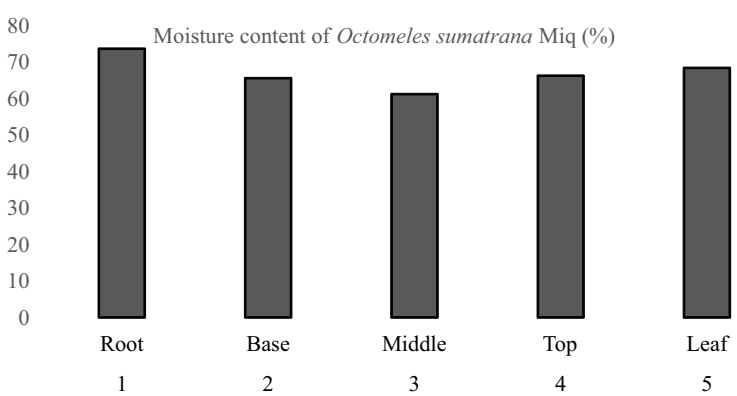

Figure 2 Moisture content of wood. 
cellulose content of $49.1 \%, 23.2 \%$ of lignin, and a fiber length of $1.427 \mathrm{U}$. This shows that the specific gravity at the root is higher than the stem and branch, with the difference influenced by the constituent components of the cell wall, namely the accumulation of extractive substances at the base which causes the cell walls to be filled with these extractive substances (Khan et al., 2020). The results of carbon testing with a spectrophotometer are shown in Table 3.

Table 4 is a sample test that represents each section according to the code, absorbance, and concentration. The percentages of the test results and carbon content are shown in Table 5, with examples illustrated in Figure 3. The results

Table 2 Specific gravity of $O$. sumatrana for a section of stem, branch, and root

\begin{tabular}{lc}
\hline \multicolumn{1}{c}{ Section } & Specific gravity $\left(\mathrm{g} \mathrm{cm}^{-3}\right)$ \\
\hline Stem & 0.11 \\
Branch & 0.11 \\
Root & 0.32 \\
\hline
\end{tabular}

indicate a close relationship between carbon concentration and $O$. sumatrana wood's absorbance, as shown in Table 5 and Figure 4. Therefore, based on laboratory analysis results on carbon concentration and absorbance, there is a very close relationship, as shown in Figure 5 with a simple regression equation: $\mathrm{Y}=0.002 \mathrm{X}+0.0593$ with an $\mathrm{R}^{2}$ value of 0.9896 . This means that an increase in carbon concentration leads to a rise in the $O$. sumatrana tree's absorbance. Therefore, this regression equation can be used in calculating the carbon concentration sample for the $O$. sumatrana tree fraction.

The calculation result of carbon stock in the roots, stems, branches, and leaves of the first tree is $3.93 \%, 19.32 \%$, $2.67 \%$, and $15.29 \%$, respectively. In the second tree, they are $8.01 \%, 20.67 \%, 2.35 \%$ and $15.52 \%$, while in the third, they are $1.75 \%, 20.60 \%, 5.58 \%$ and $16.64 \%$. The average calculation of the carbon content percentage is $4.56 \%$ (roots), 20.20\% (stems), 3.53\% (branches), and 15.815\% (leaves) (Table 6). This shows that the highest percentage of carbon content is found in the stem, followed by the leaves, roots, and branches.

Table 3 Average carbon content of $O$. sumatrana wood species

\begin{tabular}{lccccc}
\hline \multicolumn{1}{c}{ Sample } & Absorbance & $\begin{array}{c}\text { Weight } \\
(\mathrm{mg})\end{array}$ & $\begin{array}{c}\text { Carbon concentration } \\
(\mathrm{ppm})\end{array}$ & $\begin{array}{c}\text { Carbon content } \\
(\%)\end{array}$ & $\begin{array}{c}\text { Weight carbon content } \\
(\mathrm{g})\end{array}$ \\
\hline Leaf & 0.2207 & 0.0255 & 80.6833 & 15.81 & 0.0040 \\
Branch & 0.0953 & 0.0255 & 3.5352 & 3.53 & 0.0009 \\
Stem tip & 0.1217 & 0.0255 & 31.1833 & 6.14 & 0.0015 \\
Stem middle & 0.1243 & 0.0255 & 23.1833 & 4.56 & 0.0012 \\
Stem base & 0.1370 & 0.0255 & 38.8000 & 7.64 & 0.0019 \\
Root & 0.1057 & 0.0255 & 23.1833 & 4.56 & 0.0012 \\
\hline
\end{tabular}

Table 4 The carbon content (\%) and carbon content (g) of each section of $O$. sumatrana wood were based on the sample weight test $(\mathrm{mg})$ in the laboratory using spectrophotometry

\begin{tabular}{cccccc}
\hline Sample & Absorbance & $\begin{array}{c}\text { Concentration } \\
(\mathrm{ppm})\end{array}$ & $\begin{array}{c}\text { Sample weight } \\
(\mathrm{mg})\end{array}$ & $\begin{array}{c}\text { Carbon content } \\
(\%)\end{array}$ & $\begin{array}{c}\text { Weight carbon content } \\
(\mathrm{g})\end{array}$ \\
\hline DB1 & 0.214 & 77.35 & 25.3 & 15.29 & 0.0039 \\
DB2 & 0.217 & 78.85 & 25.4 & 15.52 & 0.0039 \\
DB3 & 0.231 & 85.85 & 25.8 & 16.64 & 0.0043 \\
PB1 & 0.123 & 31.85 & 25.9 & 6.15 & 0.0016 \\
PB2 & 0.170 & 55.35 & 25.0 & 11.07 & 0.0028 \\
PB3 & 0.118 & 29.35 & 25.8 & 5.69 & 0.0015 \\
AB1 & 0.100 & 20.35 & 25.9 & 3.93 & 0.0010 \\
AB3 & 0.077 & 8.85 & 25.3 & 1.75 & 0.0004 \\
AB2 & 0.140 & 40.35 & 25.2 & 8.01 & 0.0020 \\
UB1 & 0.124 & 32.35 & 25.1 & 6.44 & 0.0016 \\
UB2 & 0.119 & 29.85 & 25.6 & 5.83 & 0.0015 \\
UB3 & 0.122 & 31.35 & 25.5 & 6.15 & 0.0016 \\
CB1 & 0.087 & 13.85 & 25.9 & 2.67 & 0.0007 \\
CB2 & 0.083 & 11.85 & 25.2 & 2.35 & 0.0006 \\
CB3 & 0.116 & 28.35 & 25.4 & 5.58 & 0.0014 \\
TB1 & 0.128 & 34.35 & 25.5 & 6.73 & 0.0017 \\
TB2 & 0.097 & 18.85 & 25.0 & 3.77 & 0.0009 \\
TB3 & 0.148 & 44.35 & 25.3 & 8.76 & 0.0022 \\
\hline
\end{tabular}

Note: $\mathrm{DB}=$ binuang leaf, $\mathrm{PB}=$ binuang stem base, $\mathrm{AB}=$ binuang root, $\mathrm{UB}=$ binuang stem tip, $\mathrm{CB}=$ binuang branch, $\mathrm{TB}=$ binuang stem middle 
The calculation results in Table 7 above show that the first tree has a d.b.h of $9.24 \mathrm{~cm}$ with a height, biomass content, carbon storage, and absorption rates of $8.5 \mathrm{~m}, 3.718 \mathrm{~kg}, 1.386$ $\mathrm{kg}$, and $5.088 \mathrm{~kg}$. The total carbon sequestration of the first tree is $9.487 \mathrm{~kg}$, with an annual absorption rate of $1.581 \mathrm{~kg}$ year $^{-1}$. The second tree has a dbh of $10.08 \mathrm{~cm}$, with a height, biomass content, carbon storage, and absorption rates of $8 \mathrm{~m}$, $4.103 \mathrm{~kg}, 1.581 \mathrm{~kg}$, and $5.803 \mathrm{~kg}$. The second tree's total carbon sequestration is $10.689 \mathrm{~kg}$, with an annual carbon sequestration rate of $1.782 \mathrm{~kg}_{\text {year }}{ }^{-1}$. The third tree with d.b.h

Table 5 Carbon content of $O$. sumatrana

\begin{tabular}{ccc}
\hline $\begin{array}{c}\text { Glucose } \\
\text { concentration }\end{array}$ & $\begin{array}{c}\text { Carbon } \\
\text { concentration }(\mathrm{ppm})\end{array}$ & $\begin{array}{c}\text { Absorbance } \\
\text { standard }\end{array}$ \\
\hline 25 & 10 & 0.067 \\
50 & 20 & 0.112 \\
100 & 40 & 0.135 \\
150 & 60 & 0.183 \\
200 & 80 & 0.227 \\
250 & 100 & 0.256 \\
300 & 120 & 0.296 \\
\hline
\end{tabular}

of 11.68, with a height, biomass content, carbon storage, and absorption rates of $6 \mathrm{~m}, 3.718 \mathrm{~kg}, 1.592 \mathrm{~kg}$, and $5.843 \mathrm{~kg}$. The total third carbon sequestration is $17.079 \mathrm{~kg}$, with an annual carbon sequestration rate of $2.847 \mathrm{~kg}_{\text {year }}{ }^{-1}$.

The average carbon content in species $O$. sumatrana in the stem, branches, roots, and leaves was $1.52 \mathrm{~kg}(45 \%), 0.26$ $\mathrm{kg}(8 \%), 0.85 \mathrm{~kg}(25 \%)$, and $0.76 \mathrm{~kg}(22 \%)$, respectively. Therefore, the carbon stock content of $O$. sumatrana when sorted from the largest to smallest are stems, leaves, roots, and branches. This is in line with the research on carbon stocks of conventional and low-impact logging logged-over forests in East Kalimantan, which stated that the largest proportion of stored carbon is $74 \%$ found in stem (Indrajaya, 2012). The definition of dry weight biomass of organic matter living above the ground, including stems, stumps, branches, bark, seeds, and wood materials, leaves per unit area expressed in years per hectare (Quegan et al., 2019).

According to Hairiah et al. (2001), the calculation results of carbon biomass using the spectophotometry with the allometric model $\mathrm{B}=(\pi \mathrm{t} / 40) \mathrm{\rho HD}^{2}$, stated by $\mathrm{AGB}=$ $0.11 \rho \mathrm{dbh}^{2.442}$ (Ketterings et al., 2001), and modified AGB = $\exp \left(-2,699+0,976 \ln \left[\rho d b h^{2} h\right]\right)$ (Chave et al., 2014). Therefore, the allometric calculation results from (Hairiah et

Table 6 Calculation of carbon content for each tree, in the roots, stems, and leaves

\begin{tabular}{cccccccc}
\hline \multicolumn{7}{c}{ Carbon content (\%) } \\
\hline Tree & Leaf & Branch & Stem middle & Stem tip & Stem base & Root & Total \\
\hline 1 & 15.29 & 2.67 & 6.73 & 6.44 & 6.15 & 3.93 & 37.29 \\
2 & 15.52 & 2.35 & 3.77 & 5.83 & 11.07 & 8.01 & 38.54 \\
3 & 16.64 & 5.58 & 8.76 & 6.15 & 5.69 & 1.75 & 42.82 \\
\hline Total & 47.45 & 10.61 & 19.27 & 18.42 & 22.91 & 13.68 & 118.65 \\
\hline Average & 15.81 & 3.53 & 6.42 & 6.14 & 7.63 & 4.56 & 39.55 \\
\hline
\end{tabular}

Table 7 Carbon content of each section of the O. sumatrana tree

\begin{tabular}{|c|c|c|c|c|c|c|c|c|c|}
\hline \multicolumn{10}{|c|}{ Tree of O. sumatrana $1, \mathrm{dbh}: 9.24 \mathrm{~cm}$} \\
\hline \multirow{2}{*}{ No } & \multirow{2}{*}{ Section } & \multirow{2}{*}{$\begin{array}{l}\text { Specific } \\
\text { gravity }\end{array}$} & \multirow{2}{*}{$\begin{array}{l}\text { Weight } \\
\text { (g) }\end{array}$} & \multicolumn{2}{|c|}{ Biomass } & \multicolumn{2}{|c|}{ Carbon } & \multicolumn{2}{|c|}{ Carbon absorption } \\
\hline & & & & $\mathrm{g}$ & $\mathrm{kg}$ & $\mathrm{g}$ & $\mathrm{kg}$ & $\mathrm{g}$ & $\mathrm{kg}$ \\
\hline 1 & Stem & 0.11 & 33,800 & 3,718 & 3.718 & $1,386.44$ & 1.386 & $5,088.24$ & 5.088 \\
\hline 2 & Branch & 0.11 & 5,400 & 594 & 0.594 & 221.50 & 0.222 & 812.92 & 0.813 \\
\hline 3 & Root & 0.32 & 2,500 & 800 & 0.800 & 298.32 & 0.298 & $1,094.83$ & 1.095 \\
\hline 4 & Leaf & 0.26 & 7,000 & 1,820 & 1.820 & 678.68 & 0.679 & $2,490.75$ & 2.491 \\
\hline Total & & & & 693 & 6.932 & $2,584.94$ & 2.585 & $9,486.74$ & 9.487 \\
\hline \multicolumn{3}{|c|}{ Total without root } & & 5,112 & 5.112 & $1,906.26$ & 1.906 & $6,995.99$ & 6.996 \\
\hline \multicolumn{10}{|c|}{ Tree of O. sumatrana $2, \mathrm{dbh}: 10.08 \mathrm{~cm}$} \\
\hline 1 & Stem & 0.11 & 37,300 & 4,103 & 4.103 & $1,581.29$ & 1.581 & $5,803.36$ & 5.803 \\
\hline 2 & Branch & 0.11 & 3,400 & 374 & 0.374 & 144.14 & 0.144 & 528.99 & 0.529 \\
\hline 3 & Root & 0.32 & 5,400 & 1,728 & 1.728 & 665.97 & 0.666 & $2,444.11$ & 2.444 \\
\hline 4 & Leaf & 0.26 & 5,200 & 1,352 & 1.352 & 521.06 & 0.521 & $1,912.29$ & 1.912 \\
\hline Total & & & & 7,557 & 7.557 & $2,912.48$ & 2.913 & $10,688.76$ & 10.689 \\
\hline Total & thout root & & & 6,205 & 6.205 & 2,391.41 & 2.391 & $8,776.46$ & 8.776 \\
\hline \multicolumn{10}{|c|}{ Tree of $O$. sumatrana $3, \mathrm{dbh}: 11.68 \mathrm{~cm}$} \\
\hline 1 & Stem & 0.11 & 33,800 & 3,718 & 3.718 & $1,592.05$ & 1.592 & $5,842.82$ & 5.843 \\
\hline 2 & Branch & 0.11 & 9,000 & 990 & 0.990 & 423.92 & 0.424 & $1,555.78$ & 1.556 \\
\hline 3 & Root & 0.32 & 9,500 & 3,040 & 3.040 & $1,301.73$ & 1.302 & $4,777.34$ & 4.777 \\
\hline 4 & Leaf & 0.26 & 12,000 & 3,120 & 3.120 & $1,335.98$ & 1.336 & $4,903.06$ & 4.903 \\
\hline Total & & & & 10,868 & 10.868 & $4,653.68$ & 4.654 & $17,078.99$ & 17.079 \\
\hline Total & thout root & & & 7,748 & 7.748 & $3,317.69$ & 3.318 & $12,175.94$ & 12.176 \\
\hline
\end{tabular}




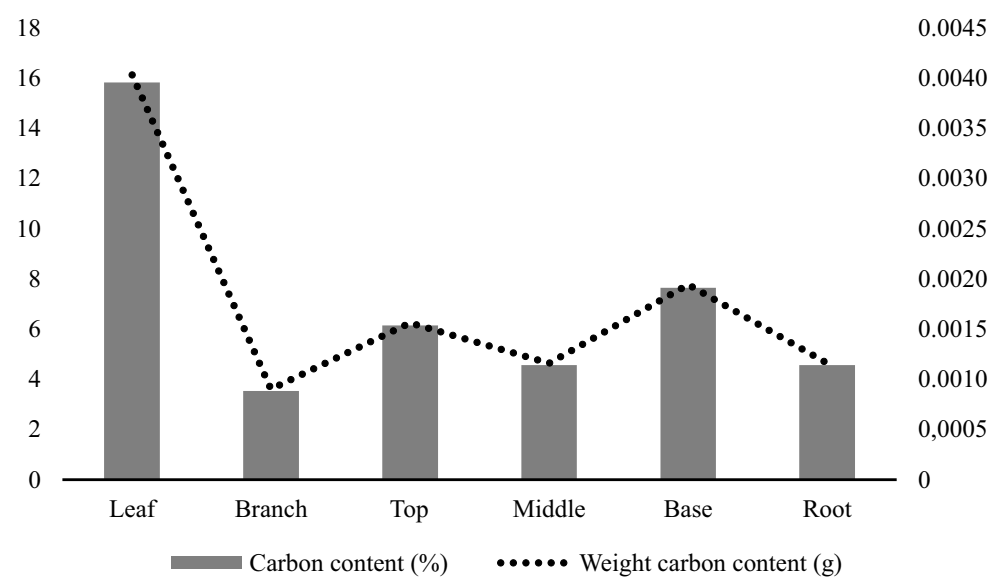

Figure 3 The test results of the average carbon content of the $O$. sumatrana wood research sample using spectrophotometry.
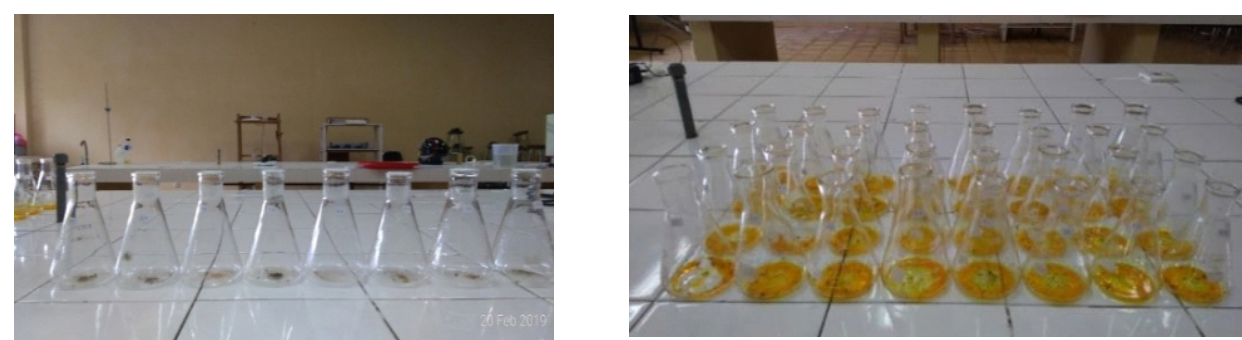

Figure 4 Analysis of spectophotometry.

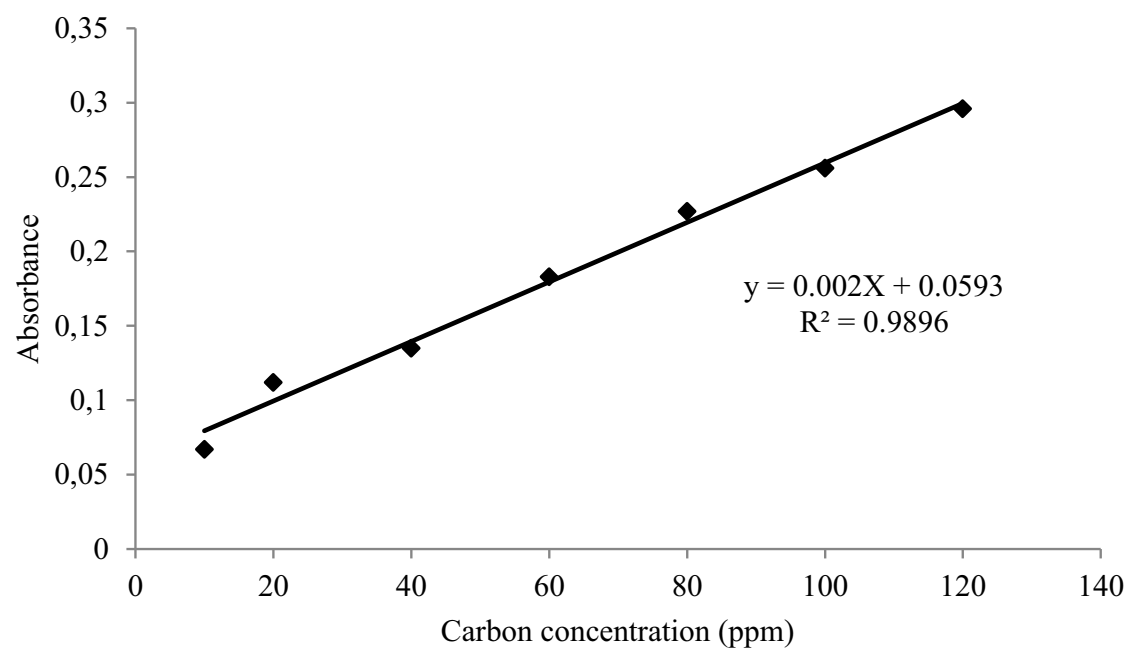

Figure 5 Carbon concentration.

al., 2001) are similar to the results in Table 8 . This is because the biomass content of a tree is strongly influenced by its diameter and site index.

According to Hairiah and Rahayu (2007), the amount of $\mathrm{C}$ stored between lands tends to vary depending on the diversity and density of existing plants, soil types, and management methods. Chairul et al. (2016) stated that these variations are also influenced by the types of forest, vegetation, climate, rainfall, topography, and other biophysical conditions, including the applied silvicultural and forest management techniques. Stas et al. (2017) reported that forest structure, age, composition, density, and quality of the growing site affect the amount of biomass produced. The highest correlation was found when combining tree volume and basic area, with the $\mathrm{R}^{2}$ value of the correlation coefficient obtained at 0.9714, which indicates a very strong correlation between volume and basic area. Chave et al. (2014) also state that the composition and structure of the forest stands affect carbon storage, with a slight difference in the calculation of carbon biomass from 
Table 8 Calculation results of carbon biomass according to various allometric equations

\begin{tabular}{|c|c|c|c|c|c|c|c|}
\hline \multirow[b]{2}{*}{ No } & \multirow{2}{*}{$\begin{array}{l}\mathrm{Dbh} \\
(\mathrm{cm})\end{array}$} & \multirow{2}{*}{$\begin{array}{l}\text { Height } \\
(\mathrm{m})\end{array}$} & \multirow{2}{*}{$\begin{array}{l}\text { Specific } \\
\text { gravity }\end{array}$} & \multicolumn{4}{|c|}{ Carbon biomass $(\mathrm{kg})$} \\
\hline & & & & $\begin{array}{c}\text { Ketterings et al. } \\
(2001)\end{array}$ & $\begin{array}{l}\text { Modiefied Chave et al. } \\
(2014)\end{array}$ & $\begin{array}{l}\text { Hairiah et al. } \\
\text { (2001) }\end{array}$ & $\begin{array}{c}\text { Method of } \\
\text { Spektrophotometry }\end{array}$ \\
\hline 1 & 9.24 & 8.5 & 0.11 & 2.760 & 4.834 & 6.267 & 5.112 \\
\hline 2 & 10.08 & 8.0 & 0.11 & 3.414 & 5.400 & 7.019 & 6.025 \\
\hline 3 & 11.68 & 6.0 & 0.11 & 4.891 & 5.437 & 7.068 & 7.748 \\
\hline
\end{tabular}

the allometric equation of statement (Hairiah et al., 2001), which confirmed that the allometric equation is local. Therefore, it cannot be applied to all places. The difference is due to variations in habitat conditions such as stand density, agro-climatic conditions including rainfall, humidity, soil fertility, and intensity of irradiation that contribute to $O$. sumatrana trees' growth, according to opinion of Lugo and Brown (1986) and Ravanini et al. (2020) that biomass is related to the proportion of wood density, the cross-sectional area of the trunk, and total height.

\section{Conclusion}

The moisture content of $O$. sumatrana starting from the stem base, middle, and tip, as well as the roots and leaves, were $65.59 \%, 61.22 \%, 66.26 \%, 73.69 \%, 68.39 \%$, respectively. The carbon content in 3 tree samples with the diameter at breast height of $9.24 \mathrm{~cm}, 10.08 \mathrm{~cm}$, and $11.68 \mathrm{~cm}$ was $2.585 \mathrm{~kg}, 2.912 \mathrm{~kg}$, and $4,654 \mathrm{~kg}$, respectively. Furthermore, each diameter per year's carbon absorption was $1.581 \mathrm{~kg}$ year $^{-1}, 1.782 \mathrm{~kg}$ year $^{-1}$, and $2.847 \mathrm{~kg}$ year $^{-1}$. Therefore, based on the results of the sample test, there is a very close relationship between carbon concentration and absorbance in the $O$. sumatrana tree with a simple linear regression equation: $\mathrm{Y}=0.002 \mathrm{X}+0.0593$ at an $\mathrm{R}^{2}$ value of 0.9896 .

\section{Acknowledgment}

The authors are grateful to the Director-General of Higher Education, Ministry of Education and Culture of the Republic of Indonesia, for funding this research through the 2019 PEKERTI research scheme.

\section{References}

Aprianis, Y., \& Rahmayanri, S. (2009). Dimensi serat dan nilai turunannya dari tujuh jenis kayu asal Propinsi Jambi. Jurnal Penelitian Hasil Hutan, 27(1), 11-20. https://doi.org/10.20886/jphh.2009.27.1.11-20

[ASTM D143] American Society for Testing and Materials. D143. (1994). Standard methods of testing small clear samples of timber. American Society for Testing and Materials-ASTM. Annual Book of ASTM, 94 ( Reapproved), 31. Retrieved from http://file.yizimg.com/175706/2011090722382624.pdf

Brown, S., \& Iverson, L. R. (1992). Biomass estimates for tropical forests. World Resource Review, 4(3), 366-384.

Chairul, Muchktar, E., Mansyurdin, M, T., \& Indra, G. (2016). The structure of vegetation density and the estimation of carbon content in some conditions of forest in Siberut Island, West Sumatera. Journal of Biological Sciences, 3(1), 15-22.

Chang, K. H., Lou, K. R., \& Ko, C. H. (2019). Potential of bioenergy production from biomass wastes of rice paddies and forest sectors in Taiwan. Journal of Cleaner Production, 206, 460-476. https://doi.org/10.1016/ j.jclepro.2018.09.048

Chave, J., Réjou-Méchain, M., Búrquez, A., Chidumayo, E., Colgan, M. S., Delitti, W. B. C., ..., \& Vieilledent, G. (2014). Improved allometric models to estimate the aboveground biomass of tropical trees. Global Change Biology, 20(10), 3177-3190. https://doi.org/10.1111/ gcb. 12629

Duncanson, L. I., Niemann, K. O., \& Wulder, M. A. (2010). Estimating forest canopy height and terrain relief from GLAS waveform metrics. Remote Sensing of Environment, 114(1), 138-154. https://doi.org/ 10.1016/j.rse.2009.08.018

Estornell, J., Ruiz, L. A., Velázquez-Martí, B., \& FernándezSarría, A. (2011). Estimation of shrub biomass by airborne LiDAR data in small forest stands. Forest Ecology and Management, 262(9), 1697-1703. https://doi.org/10.1016/j.foreco.2011.07.026

Frazer, G. W., Magnussen, S., Wulder, M. A., \& Niemann, K. O. (2011). Simulated impact of sample plot size and coregistration error on the accuracy and uncertainty of LiDAR-derived estimates of forest stand biomass. Remote Sensing of Environment, 115(2), 636-649. https://doi.org/10.1016/j.rse.2010.10.008

García, M., Saatchi, S., Ustin, S., \& Balzter, H. (2018). Modelling forest canopy height by integrating airborne LiDAR samples with satellite RADAR and multispectral imagery. International Journal of Applied Earth Observation and Geoinformation, 66, 159-173. https://doi.org/10.1016/j.jag.2017.11.017

Hairiah, K., Sitompul, S. M., \& Nooordwijk, M. N. P. C. (2001). Methods of sampling for sampling above and below-ground organic pools. IC-SEA Report No. 6: Modelling Global Change Impacts on the Soil Environment, 1-31.

Hairiah, K., \& Rahayu, S. (2007). Pengukuran karbon tersimpan di berbagai macam penggunaan lahan. World Agroforestry Centre, 77. 
Huy, B., Kralicek, K., Poudel, K. P., Phuong, V. T., Khoa, P. V., Hung, N. D., \& Temesgen, H. (2016). Allometric equations for estimating tree aboveground biomass in evergreen broadleaf forests of Viet Nam. Forest Ecology and Management, 382, 193-205. https://doi.org/ $10.1016 /$ j.foreco.2016.10.021

Indonesian REDD+ Task Force. (2012). REDD+ national strategy. Jakarta: Indonesian REDD+ Task Force.

Indrajaya, Y. (2012). Cadangan karbon hutan bekas tebangan pembalakan berdampak rendah dan konvensional di Kalimantan Timur: Studi kasus di Hutan Malinau. Jurnal Penelitian Sosial dan Ekonomi Kehutanan, 9(1), 21-30. https://doi.org/10.20886/jpsek.2012.9.1.21-30

Kailola, J. (2006). Sifat fisik beberapa jenis kayu unggulan asal Tobelo menurut ketinggian dan kedalaman batang. Agroforestry Padamara, 1(1), 5-12.

Kailola, J., Simanjuntak, R., \& Punyia, K. (2019). Kandungan kadar air $\left(\mathrm{H}_{2} \mathrm{O}\right)$ dari jenis kayu jati (Tectona grandis) dan kayu sengon (Paraserianthes falcataria) asal Tobelo Kabupaten Halmahera Utara. Agrikan: Jurnal Agribisnis Perikanan, 11(2), 311-316. https://doi.org/10.29239/j.agrikan.12.2.311-316

Ketterings, Q. M., Coe, R., Van Noordwijk, M., Ambagau', Y., \& Palm, C. A. (2001). Reducing uncertainty in the use of allometric biomass equations for predicting aboveground tree biomass in mixed secondary forests. Forest Ecology and Management, 146(1-3), 199-209. https://doi.org/10.1016/S0378-1127(00)00460-6

Khan, M. N. I., Islam, M. R., Rahman, A., Azad, M. S., Mollick, A. S., Kamruzzaman, M., ..., \& Knohl, A. (2020). Allometric relationships of stand level carbon stocks to basal area, tree height and wood density of nine tree species in Bangladesh. Global Ecology and Conservation, 22, e01025. https://doi.org/10.1016/ j.gecco.2020.e 01025

Krisnawati, H., Adinugroho, W. C., \& Imanuddin, R. (2012). Monograf model-model alometrik untuk pendugaan biomassa pada berbagai tipe ekosistem hutan di Indonesia. Bogor: Pusat Penelitian dan Pengembangan Konservasi dan Rehabilitasi

Littlefield, J. A., Marriott, J., Schivley, G. A., \& Skone, T. J. (2017). Synthesis of recent ground-level methane emission measurements from the U.S. natural gas supply chain. Journal of Cleaner Production, 148, 118-126. https://doi.org/10.1016/j.jclepro.2017.01.101

Lugo, A. E., \& Brown, S. (1986). Steady state terrestrial ecosystems and the global carbon cycle. Vegetatio, 68 , 8390 .

Luo, S., Wang, C., Xi, X., Nie, S., Fan, X., Chen, H., ..., \& Zhou, G. (2019). Estimating forest aboveground biomass using small-footprint full-waveform airborne LiDAR data. International Journal of Applied Earth Observation and Geoinformation, 83, 101922. https://doi.org/ 10.1016/j.jag.2019.101922

Mardiatmoko, G. (2018). From forest biomass to carbon trading. In E. Jacob-Lopes, \& L. Q. Zepka (Eds.), Renewable resources and biorefineries. IntechOpen. https://doi.org/10.5772/intechopen.80395.

Mardiatmoko, G., Kailola, J., Simanjuntak, R., \& Kastanya, A. (2020). The rate of absorption of carbon dioxide and moisture content in linggua (Pterocarpus indicus Willd.) for climate change management. Ecology, Environment and Conservation, 26, S415-S422

Martawijaya, A., Kartasujana I, \& Kadir K, P. S. A. (2005). Atlas kayu Indonesia (Edisi 1). Bogor: Badan Penelitian dan Pengebangan Kehutanan.

Nuraeni, Y., Anggraeni, I., \& Bogidarmanti, R. (2016). Identifikasi rayap benuang bini (Octomeles sumatrana Miq) di KHDTK Haurbentes. Jurnal Hutan Pulau-Pulau Kecil, 1(2), 9296. https://doi.org/10.30598/jhppk.2016. 1.2 .92

Nurtjahjawilasa, Duryat, K., Yasman, I., Septiani, Y., \& Lasmini. (2013). Konsep REDD+ dan implementasinya. (A. Soekadis, D. Marthinus, W. Wardojo, \& R. Bukhari, Eds.). Jakarta: The Nature Conservancy Indonesia Program.

Quegan, S., Le Toan, T., Chave, J., Dall, J., Exbrayat, J. F., Minh, D. H. T., ..., \& Williams, M. (2019). The European space agency BIOMASS mission: Measuring forest above-ground biomass from space. Remote Sensing of Environment, 227, 44-60. https://doi.org/10.1016/ j.rse.2019.03.032

Randrianasolo, Z. H., Razafimahatratra, A. R., Razafinarivo, R. N. G., Randrianary, T., Rakotovololonalimanana, H., Rajemison, A. H., ..., \& Ramananantoandro, T. (2019). Which allometric models are the most appropriate for estimating aboveground biomass in secondary forests of Madagascar with Ravenala madagascariensis? Scientific African, 6, e00147. https://doi.org/10.1016/j.sciaf.2019. $\mathrm{e} 00147$

Ravanini, F., Ferreira, R., \& Ribeiro, R. (2020). Brazil's forest restoration, biomass and carbon stocks: A critical review of the knowledge gaps. Forest Ecology and Management, 462, 117972. https://doi.org/10.1016/ j.foreco.2020.117972

Silooy, G. A. (1983). Variabilitas sfat mekanik pada kondisi kering udara dari jenis kayu makila (Litsea anggulata BI) dan lingua (Pterocarpus indicus Will) asal Kecamatan Waipia Seram Selatan Kabupaten Dati II Maluku Tengah [undergraduate thesis]. Ambon: Universitas Pattimura.

Singh, K. K., Chen, G., McCarter, J. B., \& Meentemeyer, R. K. (2015). Effects of LiDAR point density and landscape context on estimates of urban forest biomass. ISPRS 
Journal of Photogrammetry and Remote Sensing, 101, 310-322. https://doi.org/10.1016/j.isprsjprs.2014. 12.021

Stas, S. M., Rutishauser, E., Chave, J., Anten, N. P. R., \& Laumonier, Y. (2017). Estimating the aboveground biomass in an old secondary forest on limestone in the Moluccas, Indonesia: Comparing locally developed versus existing allometric models. Forest Ecology and Management, 389, 27-34. https://doi.org/10.1016/ j.foreco.2016.12.010

Suhartati, Rahmayanti, S., Junaedi, A., \& Nurrohman, E. (2012). Sebaran dan persyaratan tumbuh jenis alternatif penghasil pulp di wilayah Riau (N. Mindawati, P. Pamoengkas, U. Sutisna, \& A. P. Tampubolon, Eds.).
Jakarta: Badan Penelitian dan Pengembangan Kehutanan.

Walkley, A., \& Black, I. A. (1934). An examination of the degtjareff method for determining soil organic matter, and a proposed modification of the chromic acid titration method. Soil Science, 37(1), 29-38. https://doi.org/ 10.1097/00010694-193401000-00003

Zhang, H., Deng, Q., Hui, D., Wu, J., Xiong, X., Zhao, J., ..., \& Zhang, D. (2019). Recovery in soil carbon stock but reduction in carbon stabilization after 56-year forest restoration in degraded tropical lands. Forest Ecology and Management, 441, 1-8. https://doi.org/10.1016/ j.foreco.2019.03.037 